\title{
The local management and sustainability of swidden farming in the Villages of Bojongsalam and Sukaresmi, Upper Cisokan Watershed, West Java, Indonesia
}

\author{
IRA ROBIBATUL CHOIR ${ }^{1}$, JOHAN ISKANDAR ${ }^{1,2}$, PARIKESIT ${ }^{1,2}$, RUHYAT PARTASASMITA $^{2, \bullet}$, \\ TEGUH HUSODO ${ }^{1,2}$, JOKO KUSMORO $^{2}$, ERRI NOVIAR MEGANTARA ${ }^{1,2}$ \\ ${ }^{1}$ Postgraduate Program in Environmental Study (PSMIL \& DIL), Universitas Padjadjaran. Jl. Sekeloa Selatan I, Bandung 40132, West Java, Indonesia. \\ ${ }^{2}$ Department of Biology, Faculty of Mathematics and Natural Sciences, Universitas Padjadjaran. Jl. Raya Bandung-Sumedang Km. 21 Jatinangor, \\ Sumedang 45363, West Java, Indonesia. Tel./fax.: +62-22-7796412, `email: rp2010rikkyo@gmail.com; ruhyat.partasasmita@unpad.ac.id
}

Manuscript received: 26 March 2018. Revision accepted: 15 May 2018.

\begin{abstract}
Choir IR, Iskandar J, Parikesit, Partasasmita R, Husodo T, Kumoro J, Megantara EN. 2018. The local management and sustainability of swidden farming in the Villages of Bojongsalam and Sukaresmi, Upper Cisokan Watershed, West Java, Indonesia. Biodiversitas 19: 1054-1065. In the past, the swidden farming (huma or ladang) system had been predominantly practiced by village people of West Java. Nowadays, however, the huma farming has rarely been practiced by the village people of West Java due to the government policy, and environmental and socioeconomic changes. The local community who reside in the Villages of Bojongsalam and Sukaresmi, the upper stream of Cisokan, West Java, Indonesia, has still practiced both the wet rice field (sawah) and the huma farming in the private land, production forest of a state-owned forest company (Perhutani), and a state-owned electric company (PLN) project land. Recently some areas of the huma land have been used for the project of the Hydroelectric Power Plant of the Upper Cisokan Pumped Storage (UCPS). As a result, the sustainability of huma system of the local people of Bojongsalam and Sukaresmi has been seriously disturbed. The aims of this study were to elucidate the local management of the huma farming systems that are undertaken by local people of Bojongsalam and Sukaresmi Villages, and to analyze the sustainability of the huma farming of local people of Bojongsalam and Sukaresmi Villages as affected by the UCPS Hydroelectric Power Plant project. The qualitative method was used, while several techniques of collecting the primary data, namely observation and in-depth interviews with informants were applied in this study. The results of study showed that the local management of the huma farming has been annually undertaken by the local people of Bojongsalam and Sukaresmi, including deciding the location of huma plot, preparing the land (cutting shrubs and burning vegetation biomass), planting rice (ngaseuk) and other annual crops, weeding (ngored) and providing chemical fertilizers (mupuk), controlling pests, harvesting rice (dibuat), and fallowing land. Based on analysis of the emergent properties of the agroecosystem of huma farming, it can be predicted that productivity, stability, equitability, and sustainability of the huma farming systems of Bojongsalam and Sukaresmi Villages tend to be low in the near future due to the impact of UCPS Hydroelectric Power Plant project.
\end{abstract}

Keywords: Huma, local management, swidden farming system, sustainability, upper Cisokan

\section{INTRODUCTION}

The swidden cultivation, shifting cultivation, and slashand-burn is term for the oldest simplest form of agricultural production. Land is cleared of trees, scrub, and other vegetation, which is then burned and then land is planted with upland rice and other annual crops. After a year or two, the land is fallowed, and a new piece of land is cleared, the vegetation burned, and newly opened land planted with upland rice and other annual crops (Weinstock 2015; Ramakrishnan 2015). The swidden agriculture is called in Sundanese as huma or ladang in Indonesian. The swidden cultivation (ngahuma) system has become an inseparable culture of the Sundanese Community (Iskandar 1998). The emergence of a system or pattern of ngahuma is a stage in the evolution of human culture from the culture of hunting and gathering to the culture of farming (Hardjasaputra 2009). In other words, the model of rice cultivation in the fields is the oldest way, inherited from the period of shifting cultivation society. The main livelihood of the old Sundanese people is farming or huma (Iskandar
1998; Jamaludin 2012). Seen from the history of ecology, indeed until the early 20th century the shifting cultivation system or the huma system in Priangan and Banten Selatan was still very dominant (Geertz 1974; Iskandar 1998). However, in line with the increasing population, the decreasingly narrow forest area, and government policies, from the Dutch colonial era to the post-colonial era, the huma system of village of West Java and Banten has been formally banned by government. As a result is almost extinct in Priangan and Banten, Indonesia (Iskandar 2015; Iskandar et al. 2016).

The ngahuma system can still be found in the vicinity of the Upper Cisokan Pumped Storage Hydroelectric Power Plant (UCPS PLTA) project area. Ngahuma activity has been done for a long time and has become a culture inherited from generation to generation. Berahadang (ngahuma) has become the main livelihood for the community around UCPS Hydroelectric Power Plant Project, especially for people in Bojongsalam and Sukaresmi Villages, Rongga Sub-district, West Bandung District. Land cultivation is done on private land and state- 
owned forest company (Perhutani's) land. The construction of the UCPS Hydroelectric Power Plant Project, community farming systems in Bojongsalam and Sukaresmi Villages will be seriously disrupted, because most of farm land is lost and is used to build the UCPS Hydroelectric Power Plant Project facilities. When the project is in operation, some more farm land will be lost. As a result, the sustainability of the community system of Bojongsalam and Sukaresmi Villages will be seriously disrupted.

The aims of the study were to elucidate the local management of the huma farming undertaken by local people of Bojongsalam and Sukaresmi Villages, and to analyze the sustainability of the huma farming of local people of Bojongsalam and Sukaresmi Villages as affected by UCPS Hydroelectric Power Plant Project.

\section{MATERIALS AND METHODS}

\section{Study sites}

The research was conducted in 2 villages, namely Bojongsalam Village and Sukaresmi Village, Rongga Subdistrict, West Bandung District, West Java Province, Indonesia (Figure 1). Sukaresmi Village consists of 4 hamlets (kampong or kampung), 21 residential units called Rukun Warga (RW) and 59 neighborhood called Rukun Tetangga (RT). The number of RWs studied was 3, namely RW 1 (Lembursawah), RW 2 (Cimarel) and RW 3 (Cipateungteung). The three RWs were selected because their locations were close to the UCPS access road and Upper Dam Hydropower Projects. Bojongsalam Village consists of 4 hamlets, 12 RWs and 49 RTs. Two RWs adjacent to the UCPS Lower Dam Hydropower Project were selected, namely RW 10 (Muara, Citali, and Cangkuang) and RW 4 (Cangkuang and Langkop). The Sukaresmi Village has annual rainfall of 2000/2500 mm with humidity of $70-75 \mathrm{~g} / \mathrm{m}^{3}$, average temperature of $22^{\circ} \mathrm{C}$ and is lying at an altitude of $700 \mathrm{~m}$ above sea level, having $26-27^{\circ}$ slope. Most of the soil type in the Sukaresmi is black soil (tanah hideung). Bojongsalam Village is lying at an altitude of $923 \mathrm{~m}$ asl., having topography that varies from steep to very steep $\left(25-50^{\circ}\right.$ slope $)$ in the hills. Its average temperature ranges from $23^{\circ} \mathrm{C}$ to $26^{\circ} \mathrm{C}$ with the relative air humidity ranging from $54.2 \%$ to $93 \%$ and annual rainfall of $1650 \mathrm{~mm}$. The type of soil in Bojongsalam is clay with red/black color.

Sukaresmi Village area is 2020 ha. The area is divided into several lands uses, namely $4 \%$ as settlement, $13 \%$ cultivation land, $0.1 \%$ cemetery, $3 \%$ home garden, $0.005 \%$ office space, $57 \%$ Perhutani's land, 19\% other infrastructures, and $4 \%$ tegal/dry cultivation land. The total area of rice field is 275 ha, consisting of $47 \%$, semi-technical irrigated rice field and $53 \%$ non-irrigated rice field. In addition, Sukaresmi Village has a total area of dry land of 253 ha, consisting of 90 ha of tegal/dry cultivation land, 88 ha of settlement and 75 ha of home garden. Meanwhile, Bojongsalam Village has an area of 1313.189 ha. The area is divided into several lands uses, namely $2 \%$ as settlement, $7 \%$ rice field, $44 \%$ plantation, $1 \%$ home garden, $42 \%$ forest area, $2 \%$ other infrastructure, and $3 \%$ cultivation area. The total area of rice field is 96.685 ha, consisting of $26 \%$ of semi-technical irrigated rice field and $74 \%$ of rainfed rice field. In addition, Bojongsalam Village has a total area of 69 ha dry land comprising 51\% tegal/ladang, 32\% settlement and $17 \%$ yard. It has 576 ha of state plantation land and 545,504 ha production forest land.

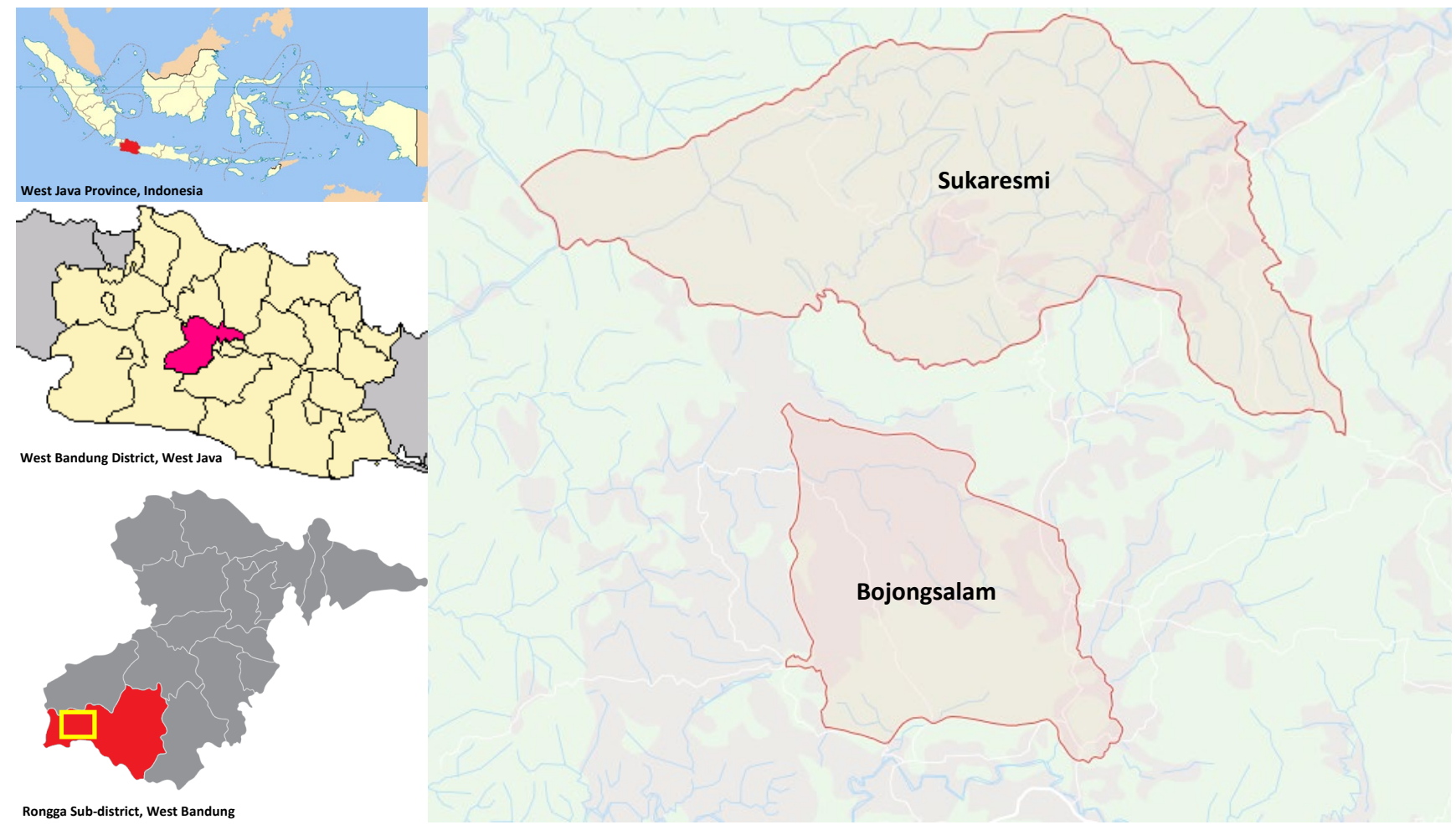

Figure 1. Map of Sukaresmi Village and Bojongsalam Village, Rongga Sub-district, West Bandung District, West Java Province, Indonesia 


\section{Research procedures}

The method used in this study was mixed-method, combination of qualitative and quantitative with ethno ecological approach was applied (Iskandar 2012a; Albuquerque et al. 2014). Qualitative data collection techniques were conducted by direct observation and semistructured, in-depth interviews with competent informant and key informants that are purposively selected. A key informant is someone who has a deep knowledge of the management of the huma system in the villages of Bojongsalam and Sukaresmi (cf. Martin, 1995; Newing et al. 2011). In addition, the structural interviews with respondents using questionnaires were carried out. The respondents were randomly selected. To decide sample number of respondent used statistical formula by Lynch et al. (1984) in this study also uses structured interviews that interview using questionnaires sheet of respondents who have been selected randomly using statistical formula. The statistical formula used in this study are based on Lynch et al. (1974) as follow:

$$
n=\frac{N \cdot Z^{2} \cdot p(1-p)}{N \cdot d^{2}+Z^{2} \cdot p(1-p)}
$$

Where:

$\mathrm{n} \quad$ : Sample size (Respondent)

$\mathrm{N}$ : Population size

$\mathrm{Z}$ : Normal variable value for $95 \%$ confidence level (1.96)

$$
\begin{aligned}
& \mathrm{p}: \text { highest proportion }(0.5) \\
& \mathrm{d}
\end{aligned}
$$

Respondents selectively have chosen based on the heads of household of 2 RWs (RW 4 and RW 10) in Bojongsalam Village and 3 RWs in Sukaresmi Village (RW 1, RW 2 and RW 3). Based on the profile data of Bojongsalam Village and Sukaresmi Village, the number of households in the designated RWs was 646 families. Therefore, on the basis of total households and is calculated by statistical formula of Lynch et al. (1974), 84 households were selected as respondents of Sukaresmi and Bojongsalam villages.

\section{Data analyses}

The results of qualitative data collection were analyzed through several stages, namely cross-checking, summarizing and synthesizing, and building up a narrative with descriptive and evaluative analysis (Iskandar 2012a, Newing et al. 2011). While quantitative data obtained from questionnaire was processed by statistical descriptive and interpreted by using Microsoft Excel 2010 software. Percentage is used to categorize land area owned by cultivators. The respondents of swidden farmers based on the swidden land ownership were categorized as large, medium and small group farmers. To analyze the sustainability of swidden farming system, the emergent properties of agroecosystems, namely productivity, stability, equity, and sustainability were applied (Conway 1986; Iskandar 2006).

\section{RESULTS AND DISCUSSION}

\section{The management of swidden cultivation}

Like common traditional management of swidden farming systems based on crops cultural ethnic groups of Indonesia, there are some stages of the swidden cultivations, namely site selection, land preparation, planting rice, managing weed and pests, harvesting rice, and fallowing land (Dove 1985; Iskandar 1998; Lahajir 2002).

\section{Site selection}

The status of huma land in the research location can be divided into two main categories, namely village farmers (customary land) and state-owned forest company (Perhutani's) land. Farmers' land is land that has been owned for generations either from purchase or inheritance. Ownership rights are fully owned by the farmers. Every farmer knows the land he/she owns. Signs of each cultivated land include the annual fruit trees such as avocado (Persea americana Mill), rambutan (Nephelium lappaceum L.), jengkol (Archidendron pauciflorum (Benth) IC Nielsen), jackfruit (Durococcus heterophylla Lam), durian (Durio zibethinus Murr), and petai (Leucaena leucocephala (Lam) de Wit).

The location of cultivated land in Bojongsalam and Sukaresmi Villages has the same characteristics, i.e., located on a sloping and steep slope (Figure 2). The striking difference between the two locations is the access road to the arable location. To reach the location of research in Bojongsalam Village namely hamlets of Citali, Cangkuang and Langkop, the only access road that can be used only by walking or two-wheeled vehicles.

Meanwhile, the location of cultivated huma in the Sukaresmi Village is more accessible, due to the opening of access road which is a UCPS Hydroelectric Power Plant Project development. Comparison of access to huma land in Sukaresmi and Bojongsalam Villages can be seen in Figure 3.

Some debris of leaves and branches are collected in the edge of swidden field and are burned (ngahuru). The purpose of ngahuru is to facilitate the farmers in perfecting the results of nyacar process and to add nutrients in the soil (cf. Rambo 1984; Christanty 1986). July-August is the months to start the process of nyacar and ngahuru because, according to the calculation of farmers, in those months the rainy season has not begun. This can facilitate the drying of the remaining plant biomass from the cutting and accelerate combustion. In addition, according to Iskandar (2011), if the plant biomass is not dry, then the combustion is incomplete, and the resulting ash is too little to add soil nutrients for the plants. As a result, the growth of rice in the fields is not good. The process of ngahuru can be seen in Figure 5.

\section{Land preparation}

Land preparation is carried out by farmers of Bojongsalam is similar to that of Sukaresmi. Starting from the clearing of shrub bush, logging if necessary, gathering 
results of burning, burning and making it into bund. The felling of trees and the removal of shrubs is called the nyacar. Huma land to be cultivated this season is not the land used during the previous seasons, because there are still non-harvested rice crops, and this is the method intended for the restoration of the land (reuma). The duration of reuma is usually 2-3 years. Within 2-3 years, of course, many wild plants invade the cultivated land. It is these wild plants that are cut and cleared for the land to be planted. The cutting shrubs (nyacar) is usully carried out in July-August, Time allocation for conducting lama nyacar depends on size of swidden plot, season, and number of labor involved. Traditional tools are used in nyacar namely, ax (kampak), chopping knife (parang), hard wood stick (aseuk), and hoe (pacul). The condition of the land that shrubs and other vegetation have been cut can be seen in Figure 4.

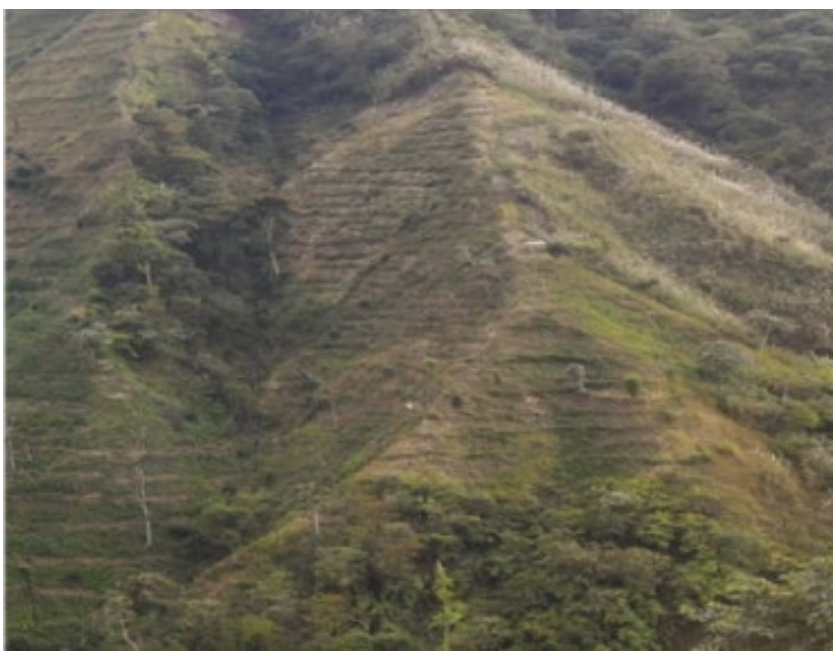

Figure 2. Huma condition in Hamlet of Langkop, Bojongsalam Village (PPSDAL 2017)

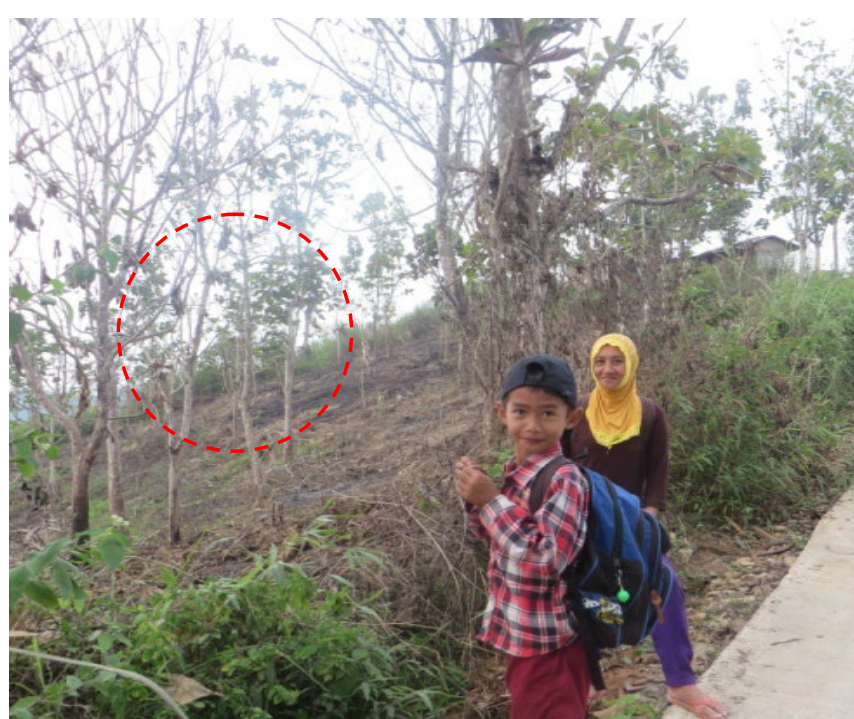

A
After ngahuru, the land is left fallow for approximately 1 month, waiting for the planting season (ngaseuk). The remaining combustion in the form of logs is collected and made like bunds (galuran). It is aimed at protecting the soil from erosion during the rainy season. Galuran is a farmer's way of conserving soil and water.

\section{Planting rice}

An important part of the management of huma is the cultivation. Planting in Bojongsalam and Sukaresmi Villages is known as ngaseuk. Planting is done in November, because, according to farmers, in this month the rainy season has started. There is no special day to start the ngaseuk process at the research location. This is in contrast to the tradition of the Baduy who choose a good day based on experience of previous cultivation success, for example coinciding with the day of birth or wedding (Iskandar 2011).

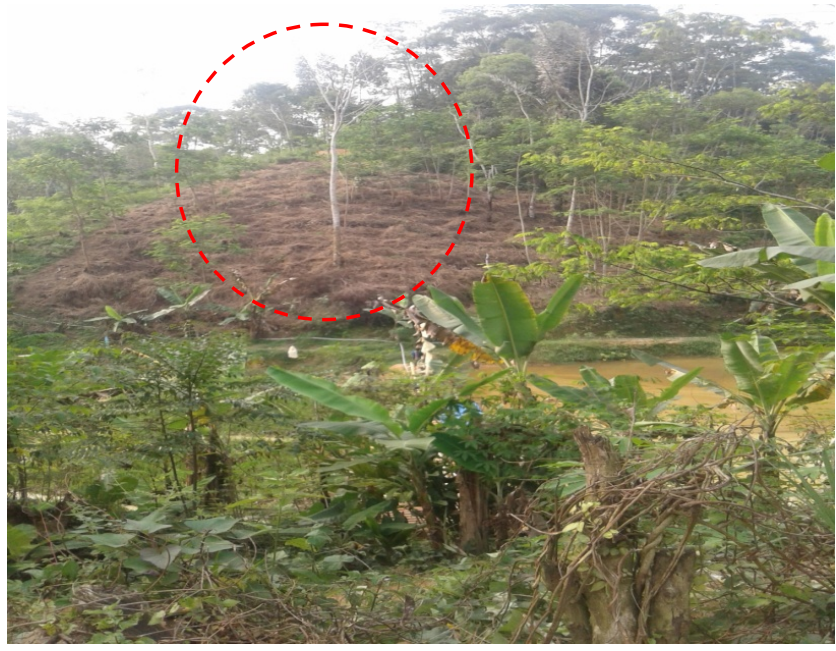

Figure 4. The new field has been prepared by total cutting shrubs (nyacar)

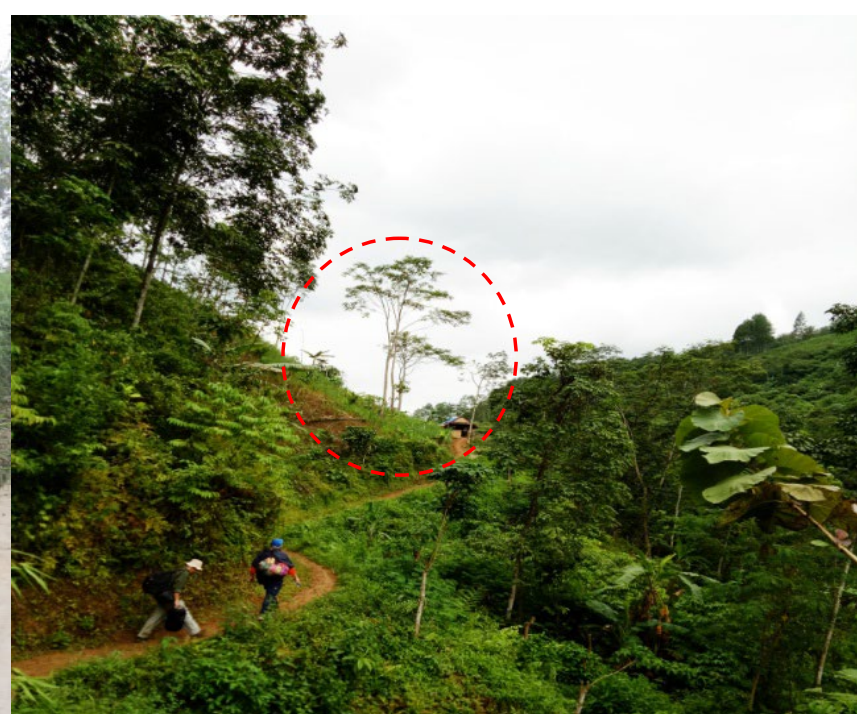

B

Figure 3. Arable land (red circle) in: A. Sukaresmi Village (Pasirlaja/Babakan Bandung RW 1), and B. Bojongsalam Village (Citali RW 10) 


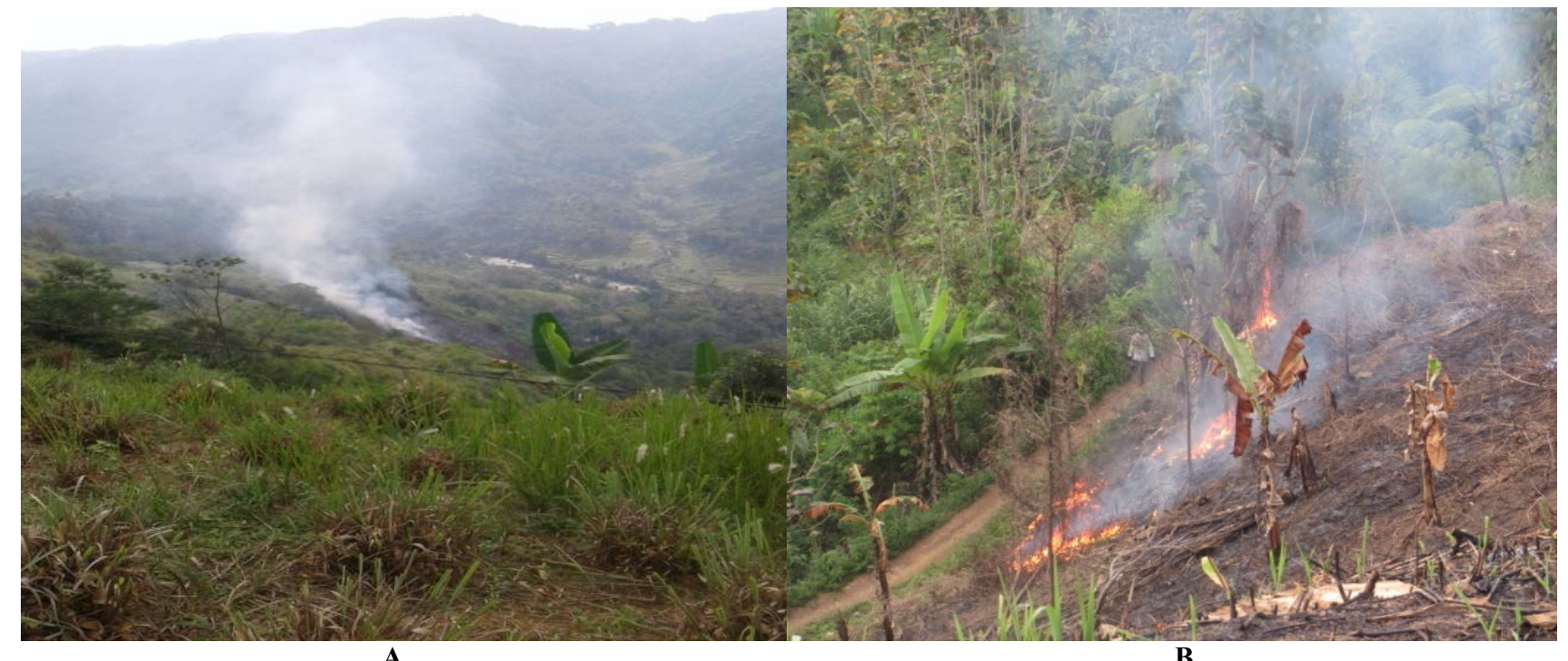

$\mathbf{A}$

B

Figure 5. Ngahuru process in: A. Bojongsalam Village (Cangkuang Hamlet RW 4), and B. Sukaresmi Village (Cimarel Hamlet RW 1)

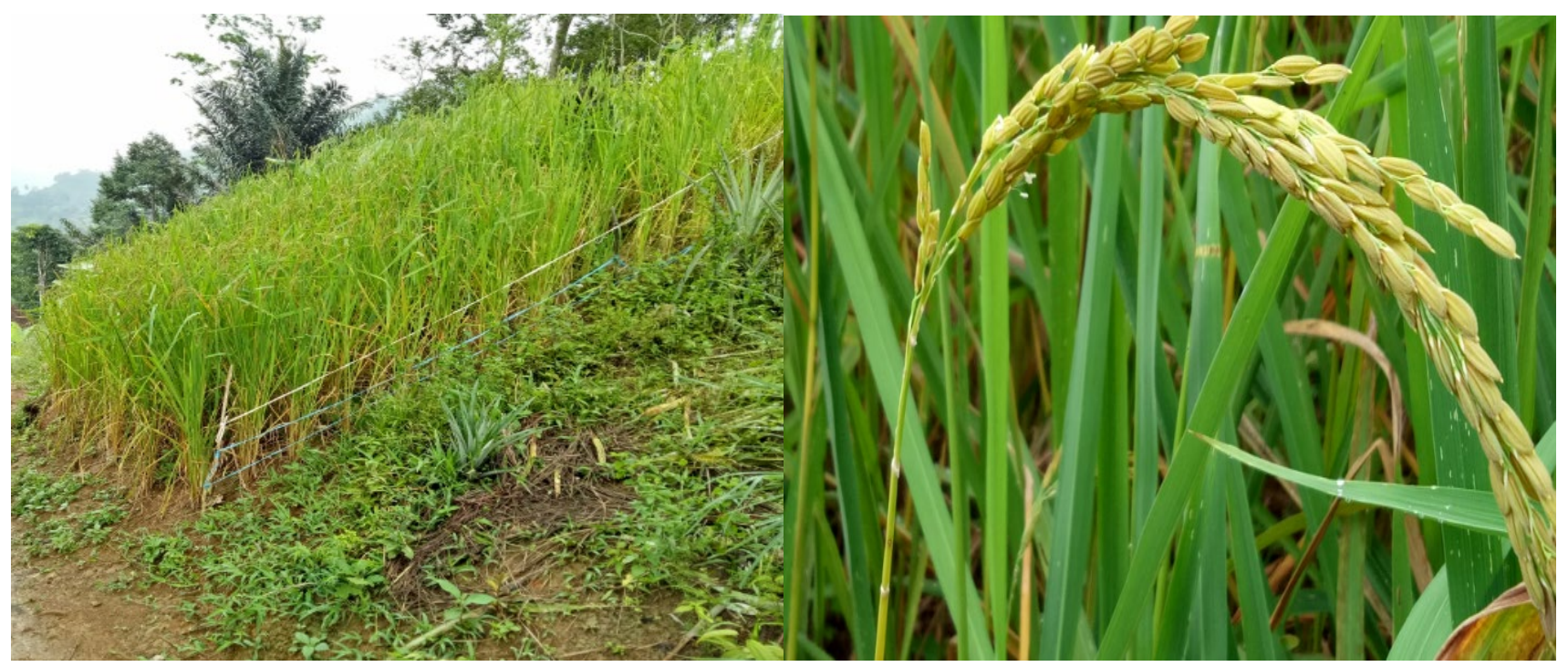

Figure 6. Type of huma rice

The types of crops grown on huma land are very diverse, consisting of rice and non-rice crops. The rice varieties grown are the local ones, such as, in local terms, pare type of bodas, beureum betric, oman, hawara, and sintung. Some farmers grow sticky rice on their land. However, about $90 \%$ of the rice species grown during the study were pare bodas and pare beureum. According to farmers, local rice of this type is superior rice, resistant to pest and disease, with a harvesting age of 6 months. The type of rice planted during the research can be seen in Figure 6.

\section{Managing weeds and pest}

Approximately two weeks after planting rice (ngaseuk), weeding (ngoyos/ngored) is done with the aim of clearing the land of huma from the weeds that disrupt the main crops. At one ngahuma season, weeding is done at least 2 times. The second weeding is commonly referred to as mindo. Ngoyos and mindo usually done by women, using tools such as machete, sickle, and weeding hoe. The duration of weeding depends on the size of the land and the number of laborers that help. Fertilization and extermination of pests are commonly done simultaneously with weeding (ngoyos and mindo). Fertilization is also done 2 times per season. Most farmers in Bojongsalam Village use urea and phonska fertilizers. Meanwhile, farmers in Sukaresmi Village use additional NPK fertilizers in addition to urea and phonska fertilizers. This is because access to roads and information from outside is easier. Manure is provided only in addition to inorganic fertilizers. Huma land is inseparable from pest attacks. Common pests that attack the huma land are caterpillars, kungkang 
(Leptocorisa acuta), kuuk (insect larvae in the soil), wild pigs, monkeys, and porcupines. In 2016-2017 the rice of swidden farming (huma) was also attacked by the brown plan hopper/BPH (wereng coklat $=$ Nilaparvata lugens Stal). Firstly BPH attacked rice of wet-rice field. Later on, the BPH also attacked the swidden farming. The eradication of BPH and caterpillars is done using artificial synthetic pesticides purchased at the store. They usually use spray pesticides or mixed with fertilizer. Farmers at the study sites did not understand how to eradicate the pest with natural pesticides, unlike the Baduy who control the pest using medicinal plants such as cangkudu (Momordica charantia L.), rimpang laja/laos (Languas galanga (L.) Stuntz), green coconut water (Cocos nucifera L.), orange peel (Citrus grandis L.), tawak kawung/aren (Arenga stylists (L.) Osbeck), fermented palm sugar juice (tuwak kawung/aren-Arenga pinnata (Wurmb) Merr) and kitchen ash (lebuh hawuh) are predominately applied by the Baduy community. The bio pesticides material are spread by hand over the swidden. To provide bio pesticides in the rice of swidden farming is called as treat of rice (ngubaran pare) (Iskandar 2012). Meanwhile, to ward off wild boars and monkeys, the peasants usually guard their huma land, especially in the evenings from the huts they deliberately built. The boars and monkeys have only driven away with sticks, flashlights and farmers' shouts when the night comes. In addition, there is a wild boar hunting culture (moro) which is usually done 2 times a week. At least, this can help reduce the wild boar attack to huma land.

\section{Harvesting rice}

Rice can be harvested after 6 months of planting, around May-June. While non-rice crops, have shorter or longer harvest period than the huma rice (Figure 7). Corn, cucumbers and other vegetables can be harvested about 3-4 months after planting. Rice harvesting is done using a tool called ani-ani. The amount of labor required depends on the size of the cultivated area. The labor system is also widely applicable in both Bojongsalam and Sukaresmi Villages. The worker is paid with wages in the form of money and grain (bawon). The daily wage for a man is 40,000 IDR and bawon as much as $10-20 \mathrm{~kg}$. Meanwhile, the daily wage for a woman is 35,000 IDR. However, if the land is not too large, rice harvest is done by family members only.

The harvest of unhulled rice paddy is directly transported to the farmer's house. Farmers greatly avoid storing crops in the fields. Then, the grain is dried in the sun until it can be stored for a long time. The huma rice grain is usually sold if the farmer gets a surplus crop. Approximately $90 \%$ of farmers in Bojongsalam and Sukaresmi Villages normally cultivate the swidden farming together with cultivation the wet-rice fields. The rice grain from the wet-rice fields is consumed every day and sold, while the rice of swidden farming (huma) is stored to be used as seeds in the next swidden cultivation. However, the rice of swidden farming can be sold in terms of seed rice (benih) instead of grain (gabah). Generally seeds of rice of wet-rice field are commonly sold in farm shops, but seeds are rarely sold in the farm shop.

\section{Fallowing land}

Rice harvest leaves only straw and non-harvested plant residues that have not been harvested. The situation in local terms is called jami. Jami which is more than 3 months old is called reuma. Reuma is a term for huma land that is left fallow (Figure 8).

The duration of reuma at the study sites varies from 1 year to 3 years. It depends on several conditions. One of them is that there are new non-rice plants that can be harvested after rice. For example, a banana plant produces fruit after 2 years, then duration of reuma will be left fallow until all the bananas are harvested. If many new trees are planted, then the period of reuma can be long, because many new trees can be harvested after more than 3 years (Figures 9 and 10).

\section{Sustainability of swidden system}

To analysis sustainability system of swidden farming of Bojongsalam and Sukaresmi is focused on 6 emergent properties of agroecosystems, namely productivity, stability, equitability, and sustainability are applied (Conway 1984, 1986; Iskandar and Abdoellah 1988; Marten 1988; Rerkasem and Shinawatra 1988).

\section{Analysis}

Productivity in agriculture is the result of a harvest from the entire area. The total area of cultivated land in this study was 16.69 ha. This area was the total of all land areas regardless of ownership status. Productivity is calculated on the basis of land area, i.e. small, medium and large land area, using the following formula:

$$
\text { Productivity }=\text { Yield }(\text { ton }) \times(1 / \text { cultivated area })(\text { ha })
$$

Productivity in small or narrow land was 1.14 tons/ha, the productivity of moderate land category is 2.285 tons/ha, while the productivity the big land area was 2.624 tons/ha. The productivity figures if multiplied by the total area will result in the production figures. The production potential of cultivated cultivation on the narrow land of the season was 18.97 tons, on the moderate land 38.11 tons and the land area 43.8 tons. These numbers apply to existing conditions.

The prediction of the production value under the condition of the UCP power plant if it is in operation shows a change, assuming that PLN's land cannot be used as a plot again. The change in production value after the cultivated land is reduced to small/narrow land category is 9.28 tons, on the medium 18.65 tons and the large land 21.41 tons. Comparison of productivity of existing condition with current operation of UCP power plant can be seen in Table $1 . \square$

\section{Stability analysis}

Stability is a production level that can be used under normal constant conditions, although environmental conditions are changing (Conway 1986). In this study, the indicators that can be used are project, pest, and population. 


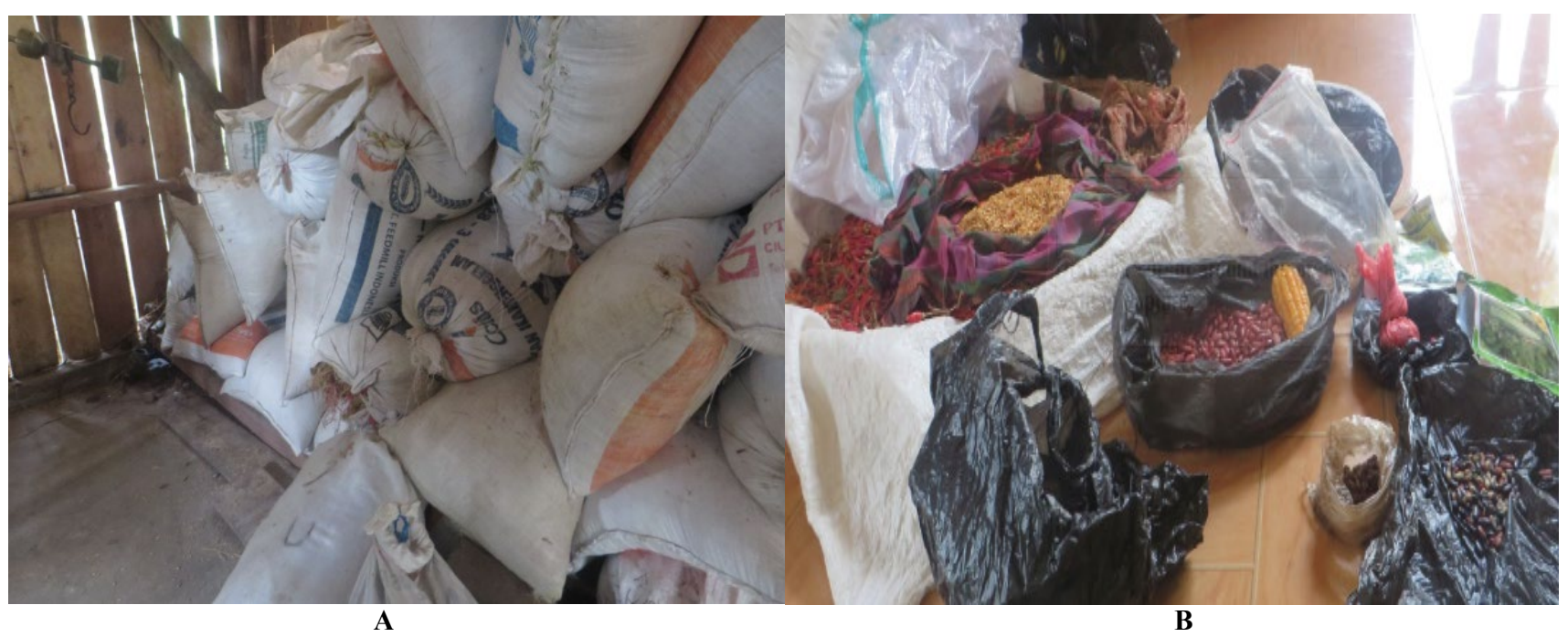

Figure 7. Paddy (A) and non paddy (B) yields last season

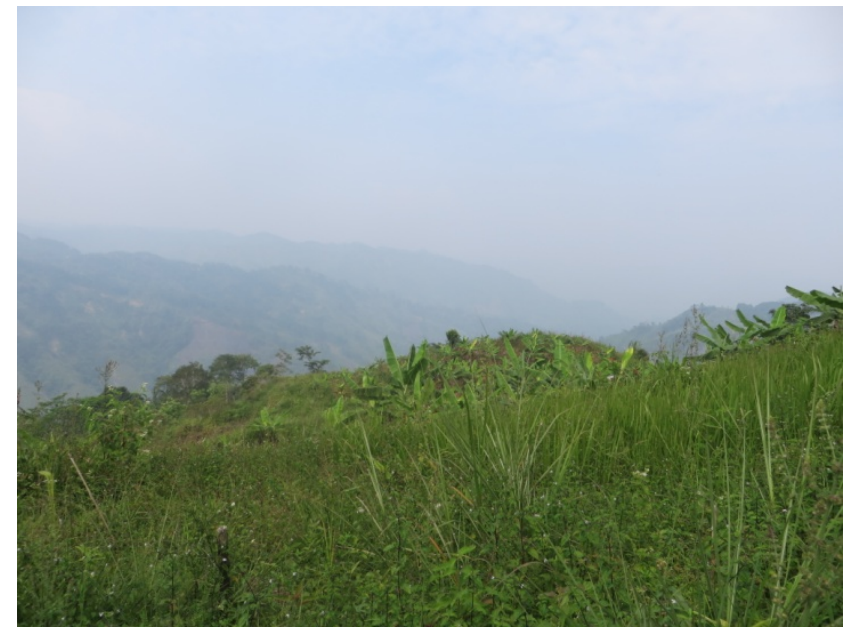

Figure 8. Jami condition

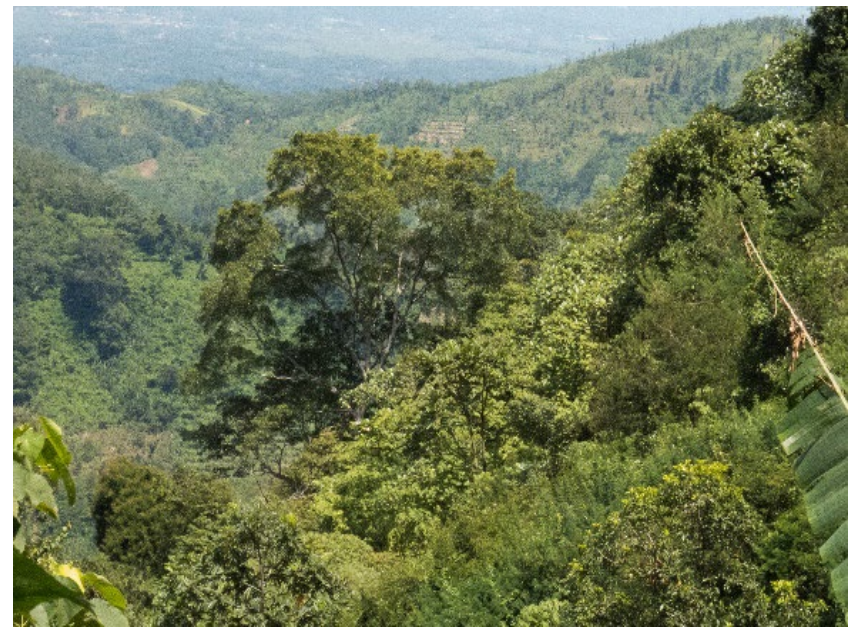

Figure 10. Vegetation conditions of the former huma bush at the observation site (PPSDAL 2017)

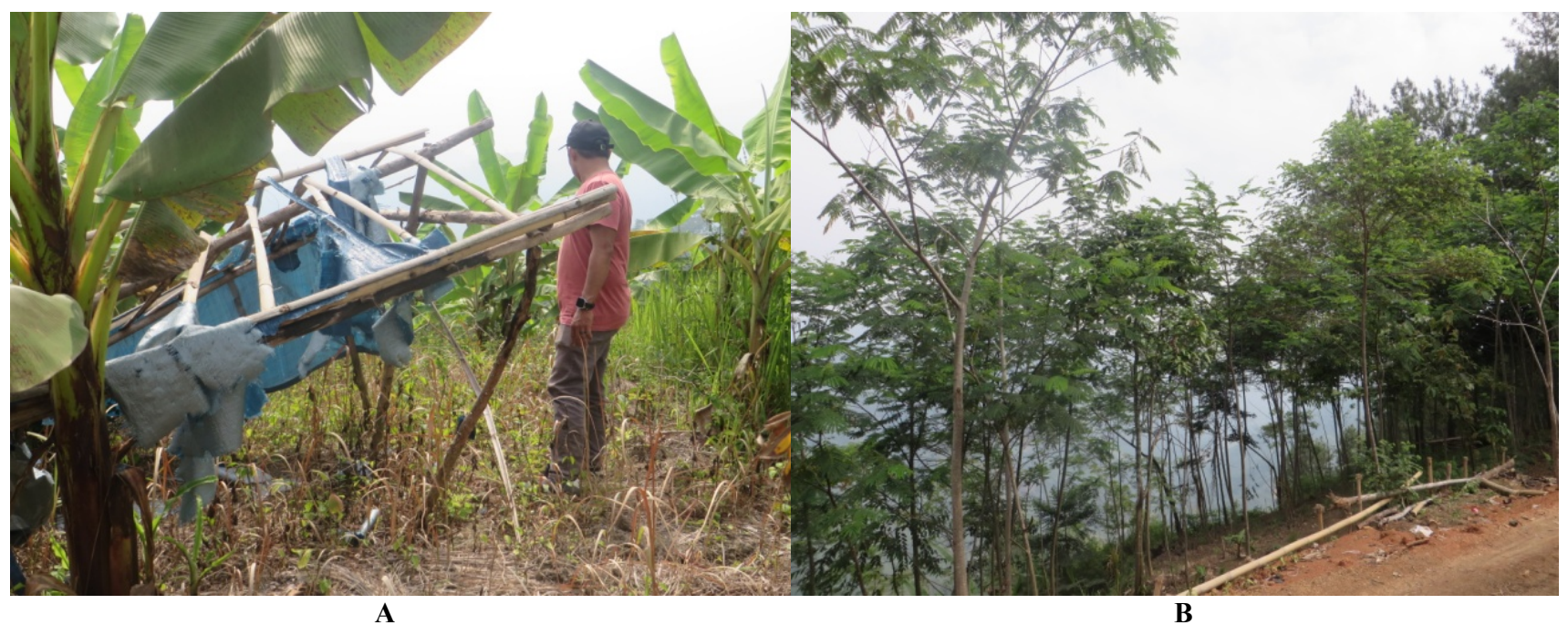

Figure 9. The conditions of one-year-old reuma (A) and 3-year-old reuma (B) 
Pressure is defined as circumstances of a suitably customizable nature, occasionally but sustained, relatively small or light, and can be recalculated (Conway 1986). At the stage of the research being undertaken it is the UCPS Hydroelectric Power Plant project development process, starting from the land acquisition until the hydropower is in operation. Based on the PLN (2007) report, the construction of UCPS Hydroelectric Power Plant and its infrastructure cover 775.64 ha, separated in two districts, West Bandung District and Cianjur District which have UCPS Hydroelectric Power Plant, i.e.: (i) Construction of main construction (power house, surge tank, switchyard, upstream dam and downstream dam), (ii) Access road (27.5 $\mathrm{km}$ long access road), (iii) upstream and downstream inundated areas (iv) Transmission lines and quarry and landslide areas.

UCPS Hydroelectric Power Plant development plan and its infrastructure area of 775. 64 ha (PLN 2007) is administratively located in two regencies, namely West Bandung District and Cianjur District. Based on the land cover types of Perhutani III, especially the Management Unit (KPH) of Bandung Selatan and KPH of Cianjur, the type of land use in the project area is divided into natural areas covering natural forests and cultivated areas grown with pine/mahogany/rasamala production forest, mixed/ talun/agroforestry, shrubs/fields/fields, fields and yard/ settlement. From the types of land use, the largest land use is pine forest/mahogany production, reaching 5,001.86 Ha $(58 \%)$. Production forest areas are scattered throughout the study area, and other land uses for the project site were as large as $3,947,046$ ha $(24 \%)$, fishponds/ponds $2,302,443$ ha (14\%), settlements and home garden 657,8409 ha $(4 \%)$ (PPSDAL 2014).

In production forest areas of KPHs of Cianjur and South Bandung an enabling environment was also within the forest area of Perhutani production. Administratively some lands of the village community located in production forest and used as site of the UCPS Hydroelectric Power Plant. Those of land consists of perennial mixedgarden/'talun'/agroforestry, wet-rice field/fish pond, and home garden/settlement Administratively UCPS project of PT PLN is a type of land use in community land consists of mixed/talun/ agroforestry, fish/fish ponds, and yard/settlement. Based on the report of the Biodiversity Management Plan (PPSDAL 2014), the total area of community land is 310.07 ha of land consisting of paddy field/fish pond of 189.74 ha and yard/settlement and garden/talun/agro-forestry area 120.33 ha. The widespread sites of UCPS Hydroelectric Power Plant projects in research sites can be seen in Table 2 .
At the time of research, the development process that had been done was part of the main construction, access road, and transmission lines. Meanwhile, the inundation had not been done, because the UCPS Hydroelectric Power Plant had not operated at maximum capacity and was still at the stage of land acquisition. Exemption is done on land owned by the population and owned by Perhutani. In general, UCPS development activities will cause many pieces of land to be inundated. Land clearing and population movements to areas around the inundated areas cause an increase in population pressure on land. Population movements were still ongoing when this research was conducted. Resettled residents are residents of resettlement and agricultural land already used for project development. The sketch of the land of Perhutani and the location of the resettlement plan can be seen in Figure 11.

Unpredictable weather changes are feared to pose a threat of pest explosion on huma land. This is based on the occurrence at the time the research was taking place, when there was an explosion of aphis that attacked the rice fields in all the research sites. Previously, aphis had never attacked the huma field, but in the planting season of 20162017, the pest also attacked the rice. The habit of using insecticides for eradicating pests,may cause pesticide resistance in aphis.

Based on the research results, the stability of the existing condition, seen from the project pressure indicator, pest disturbance and the number of population was still at the medium stage. This is based on the existence of large number of farmers who were still working on the land despite a lot of pressure that occurred, with production that was not much different from the previous cultivation. This condition was possible because the project had not been fully operated, so farmers felt that their cultivation land was still large. If the puddles and other project facilities have been optimally operated, there will be no possibility of land grabbing of arable land, settlement land and wildlife habitat. Stability predictions will be low if available land becomes narrow or lost due to submersion of land. Existing stability conditions and the future predictions after UCPS Hydroelectric Power Plant operate can be seen in Figure 12.

Table 1. Comparison of production values under existing conditions and under UTA hydroelectric conditions already in operation (prediction)

\begin{tabular}{|c|c|c|c|}
\hline Production value & $\begin{array}{c}\text { Small land } \\
800 \mathrm{~m}^{2} \text { (ton) }\end{array}$ & $\begin{array}{l}\text { Moderate land } \\
\mathbf{2 0 0 0} \mathbf{~ m}^{2} \text { (ton) }\end{array}$ & $\begin{array}{c}\text { Big land } \\
5000 \mathrm{~m}^{2} \text { (ton) } \\
\end{array}$ \\
\hline Existing & 18.97 & 38.11 & 43.8 \\
\hline Prediction & 9.28 & 18.65 & 21.41 \\
\hline
\end{tabular}

Table 2. Land requirements of UCPS Hydroelectric Power Plants and administration limits

\begin{tabular}{|c|c|c|c|c|c|c|c|c|c|}
\hline \multirow[b]{2}{*}{ District } & \multirow{2}{*}{$\begin{array}{l}\text { Sub- } \\
\text { district }\end{array}$} & \multirow[b]{2}{*}{ Village } & \multicolumn{7}{|c|}{ Location within the project site } \\
\hline & & & $\begin{array}{c}\text { Main } \\
\text { construction }\end{array}$ & $\begin{array}{c}\text { Upstream } \\
\text { inundated area }\end{array}$ & $\begin{array}{c}\text { Downstream } \\
\text { inundated area }\end{array}$ & $\begin{array}{c}\text { Connecting } \\
\text { road }\end{array}$ & $\begin{array}{c}\text { Transmission } \\
\text { line } \\
\end{array}$ & Quarry & $\begin{array}{c}\text { Potential of } \\
\text { landslide }\end{array}$ \\
\hline West Bandung & Rongga & Bojongsalam & + & + & - & - & - & - & - \\
\hline West Bandung & Rongga & Sukaresmi & + & + & - & + & + & - & - \\
\hline
\end{tabular}

Source: ANDAL (2007) and EIA (2009 in PPSDAL 2014) 


\section{Analysis of equality}

The social equity or equality referred to in this study is to describe the agricultural products that can be enjoyed by all levels of society and evenness in gaining control of land tenure status. Based on the previous explanation, that the ownership and control of the cultivated land is divided into private land, PLN's land and Perhutani's land.

The land of Perhutani can be traded, with the reason of replacing the cost of land processing that has been done. This condition occurred in the hamlets of Lembur Sawah and Babakan Bandung (Sukaresmi Village). The price of 1 piece of land was about 1-2 million rupiahs, depending on the fertility of the land and the position of ease of cultivation of land. Sloping land and flat land is worth more than the land.

Based on the answers of the questionnaire, the land area based on ownership status is $14 \%$ of farmers working on their land own/customary land, 33\% in Perhutani's land, $8 \%$ in state electric company's (PLN) land, $19 \%$ on private and PLN's land, $13 \%$ on the Perhutani's and their own land, 5\% on PLN's and Perhutani's land, and 7\% on their own land, Perhutani's and PLN's land. PLN's land used to belong to farmers and then was bought by PLN for hydropower needs. The percentage of cultivated land based on land ownership can be seen in Figure 13.

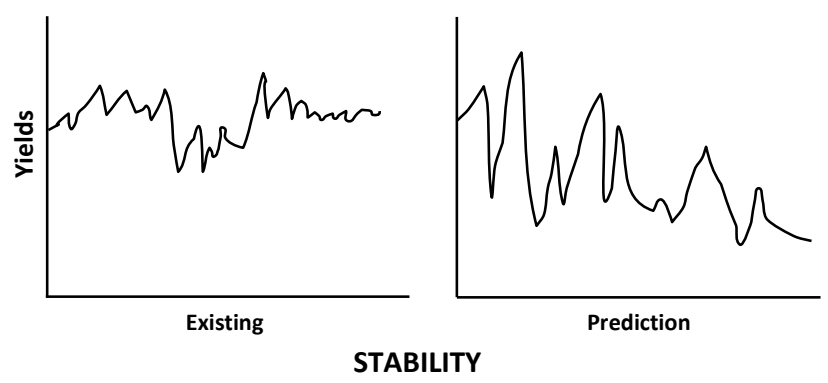

Figure 12. Condition of stability in the existing state and predictions to come

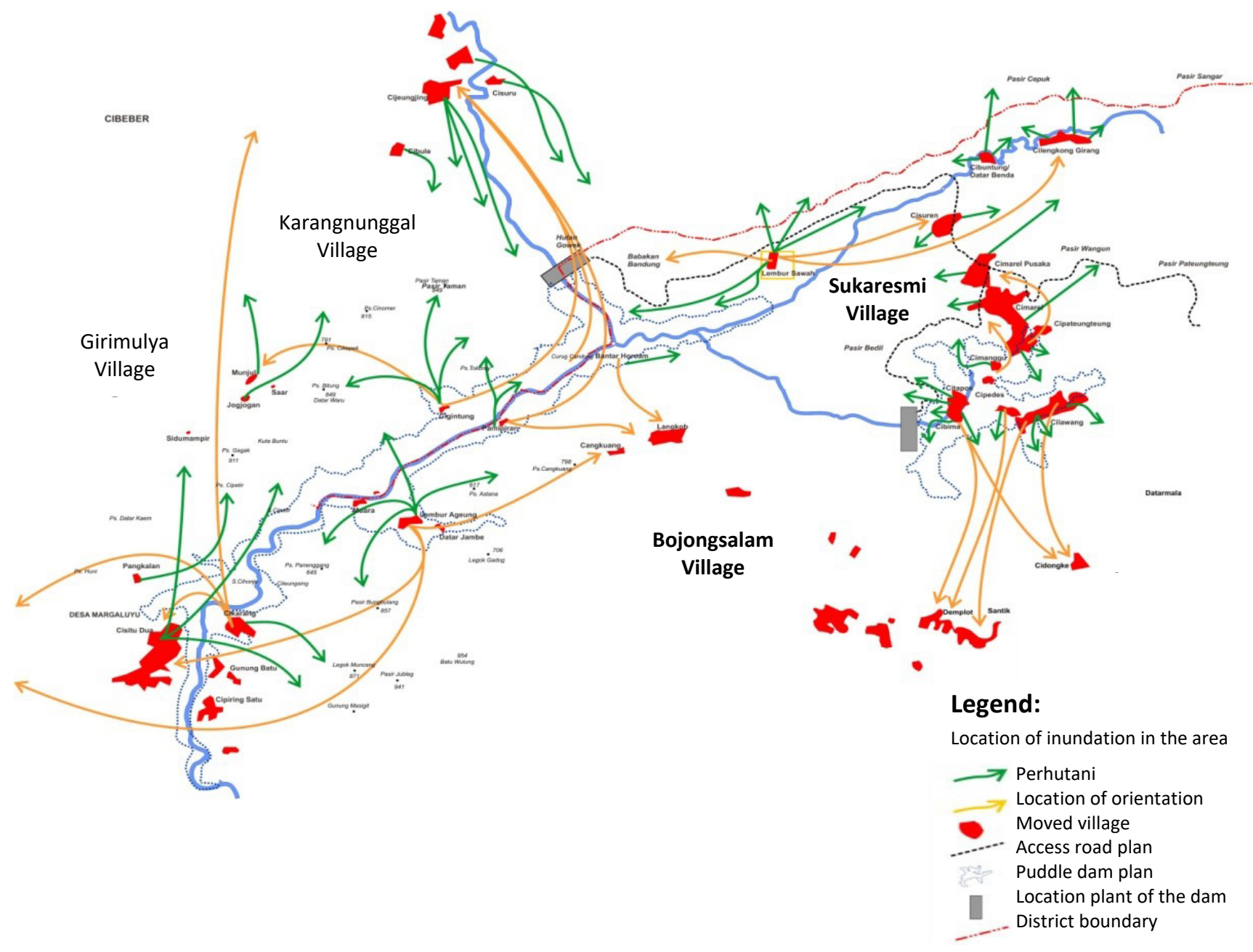

Figure 11. The sketch of the land claimed by Perhutani and the location of the resettlement plan (PPSDAL 2014) 


\section{Sustainability analysis}

Sustainability according to Conway (1986), is the ability of a farming system to maintain its productivity, although the system is subject to great stress and disturbance. Shifting cultivation generally has low productivity and stability values, but has a high value of equitability and sustainability. However, the addition of new technologies and some factors of production (input) from the outside, can increase the value of productivity but can also lower the values of others. Conway (1986) exemplifies in the case of paddy farms introduced with superior seeds (IR8), which are resistant to pests and diseases, having relatively fast harvest time and high production yields. However, their sustainability is low, because at the longer time scale, it actually causes the pests become more resistant and more external additions are required.

The huma and wetland systems in the study sites show that traditional farming has received additional external inputs aimed at increasing productivity, such as artificial chemical fertilizers, artificial pesticides, and tractors to plow the fields. However, the addition of fertilizer and pesticides differs between huma and rice field. The use of fertilizers and pesticides in huma is less than in the rice field. The addition of these external inputs will affect the output.

The value of existing production at the study site is predicted after the puddle has changed. This is due to the loss of farm land that cannot become farm land again. This land area will also affect farmers' equity in doing their work. Limited land area will cause higher land prices, so only farmers who have large capital will work on.

In addition, the stability of the existing huma system is also affected by the change in land area due to the loss to hydropower, population increase, and the allocation for habitat of 10 protected species. In the existing condition, sustainability could be considered moderate. This can be seen from the input of production output, stability and control the land of the huma system on the existing condition had not changed much with previous years. Land changes are predicted to create disturbances and pressures that cause the difficulty of farmers to cultivate land. Sustainability indicators (Productivity, Stability and Equability) on the existing and predicted conditions, after UCPS Hydroelectric Power Plant operates, can be seen in Table 3.

The sustainability of the system after inundation is predicted to shift from moderate to low. This is caused by several things. First, after the inundation is done, the area of arable land will decrease, and the population will increase. Therefore, to avoid conflict, it is necessary to regulate the right of land so that no party is harmed.

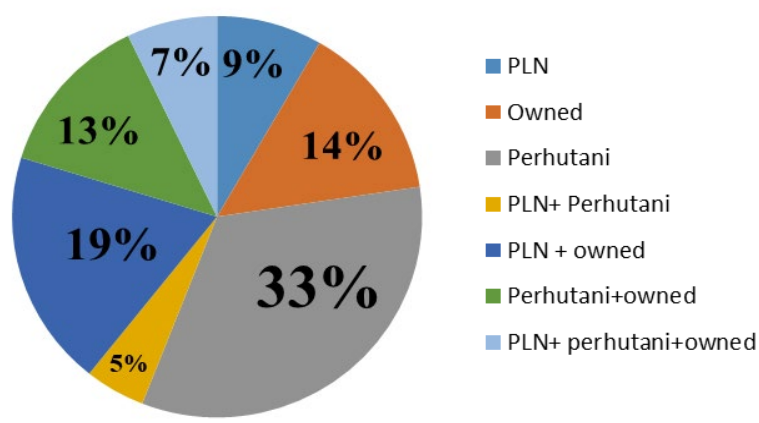

Figure 13. Percentage of huma ground land based on land ownership status

Table 3. Comparison of the nature of agroecosystem huma between the existing condition and prediction after inundation

\begin{tabular}{|c|c|c|}
\hline & Existing & Prediction \\
\hline \multicolumn{3}{|l|}{ Productivity } \\
\hline \multirow[t]{3}{*}{ Production value } & 18.97 ton & 9.28 ton \\
\hline & 38.11 ton & 18.65 ton \\
\hline & 43.8 ton & 21.41 ton \\
\hline \multicolumn{3}{|l|}{ Stability } \\
\hline Project pressure & $\begin{array}{l}\text { Access roads, transmission lines, some major } \\
\text { construction }\end{array}$ & $\begin{array}{l}\text { Access road, transmission line, upstream puddle area, } \\
\text { main construction }\end{array}$ \\
\hline Pest disorders & Wild boar, planthopper, caterpillar $\square$ & Wild boar, planthopper, caterpillar $\square$ \\
\hline \multirow[t]{2}{*}{ Total population } & Bojongsalam Village $=5197$ people & Bojongsalam Village $=\mathrm{x}<5197$ people $<\mathrm{x}$ \\
\hline & Sukaresmi Village $=8414$ people & Sukaresmi Village $=\mathrm{x}<8414$ people $<\mathrm{x}$ \\
\hline \multicolumn{3}{|l|}{ Equitability } \\
\hline Land area & $16.68 \mathrm{ha}$ & 8.16 ha \\
\hline Price of land & $500,000-1,500,000 \mathrm{IDR} / \mathrm{m}^{2}$ & $\left(500.000-1,500,000 \mathrm{IDR} / \mathrm{m}^{2}\right)<\mathrm{x}$ \\
\hline Sustainability & Moderate & Low \\
\hline
\end{tabular}


Second, local knowledge of farmers who have been derived from previous generations, is difficult to remove. Despite management changes, basic knowledge of huma management has not been replaced. For farmers with limited land, subsistence material production or income is important because their sustainability depends on them (Reijntjes 1992). Farmers, in general, have investigated the best options adapted to local circumstances and utilize them well. In this way, harmonious agricultural systems have evolved and survived from generation to generation. $\square$

Third, the ease of access to information and access roads (transportation) causes changes to social and economic in research sites. One of the changes is the increasing relationship with the industrial community/city, thus providing more money to buy industrial products. This leads to a change in the mindset of the community regarding the need for farming. The position of farming becomes a commercial orientation and not just subsistence anymore. Adaptation to increasing population pressure and changes in economic conditions in many cases have led to new practices such as the expansion of cultivation of plants to vulnerable slopes and monocultures spurred by modern varieties (Sanwal 1989).

One commercialization of commodities grown similar to that in huma is the commodity of citronella. Intensification of lemongrass has been widely planted in the Hamlet of Langkop, Bojongsalam Village. Farmers there have learned that citronella can provide higher economic value than ngahuma. In fact, in the Langkop Hamlet, there is a lemongrass distillery factory. Citronellacassava is grown in monoculture and farmers think the maintenance process is easier than huma. According to Reijntjes (1992), the decline of knowledge about local agroecosystems and local farming techniques, strategies, and local genetic resources, is due to the decline of traditional practices and agriculture as a profession.

Fourth, the huma system supports ecological conditions at the research site. High crop diversity tends to provide high stability compared to monoculture cultivation. If functional diversity can be achieved by combining complementary and related species of plant species in positive and synergetic interactions, it not only improved stability, but also productivity of agricultural systems (Reijntjes 1992).

The huma system at the current research site is mostly done on steep slopes. If no proper agricultural and soil management practices are done, serious soil erosion and water resource degradation can occur when the highlands are introduced into intensive agricultural production (Soemarwoto 1980). Appropriate highland farming systems must meet the following criteria: (i) Ecologically, the system must protect the soil from erosion, and it must provide sustainable yield without causing environmental damage. (ii) Economically, it should increase the carrying capacity of the ecosystem and must provide long-term livelihood to the people. (iii) Psychologically and politically, the society must be interrelated. Farmers operate on traditional knowledge and personal experience. The improved version of traditional farming systems has a better adoption prospect than an entirely new planting system (Valdes 1980; Christanty et al. 1986).

The persistence of the huma system at the study site to date, indicates that the system provides various benefits felt by society and the environment through local knowledge through generations. The addition of inputs outside production, such as the addition of artificial chemical fertilizers and chemical pesticides, is the response of farmers to maintain the huma system. The addition of input is obtained based on incoming information and is a trial and error in managing the system of huma in the hope of continuing to the next generation.

It can be concluded that based on analysis of the emergent properties of the Agroecosystem of huma farming, productivity, stability, equitability, and sustainability of the huma farming systems of Bojongsalam and Sukaresmi Villages tends to be low for the near future due to impact of the UCPS project.

\section{ACKNOWLEDGEMENTS}

The authors would like to thank the informants and respondents who had been very helpful during the process of this research. This paper publication is supported by ALG (Academic Leadership Grant) of Prof. Erri Noviar Megantara, with the main topic is titled as "Management of Biodiversity and Ecosystem Services in Non-Conservation Areas in West Java". Therefore, authors would like to thank Rector of Padjadjaran University, Prof. Tri Hanggono has supported the publication. We would like to thank Dean of Faculty of Mathematics and Natural Sciences, Head of Department of Biology who have been supporting this publication.

\section{REFERENCES}

Albuquerque UP, Cruz da Cunha LVF, Lucena RFP, Alves RRN (eds). 2014. Methods and Techniques in Ethnobiology and Ethnoecology. Springer Science \& Business Media, New York. $\square$

Christanty L, Abdoellah OS, Marten GG, Iskandar J. 1986. Traditional Agroforestry in West Java: The Pekarangan (Homegarden) and Kebun-Talun (Annua-.Perennial Rotation) Cropping Systems. Traditional Agriculture In Southeast Asia: A Human Ecology Perspective, Westview Press (Boulder, Colorado).

Christanty L. 1986. Shifting cultivation and Tropical Soils: Patterns, Problems, and Possible Improvements. In Marten GG (ed), Traditional Agriculture in Southeast Asia: A Human Ecology Perspective. Westview Press, Boulder, Colorado.

Conway GR. 1984. What is an Agroecosystem and Why is it Worthy of Study? In Rambo AT and PE Sajise (eds). 1984. An Introduction to Human Ecology Research on Agricultural Systems in Southeast Asia.East-West Environment and Policy Institute and University of the Philippines at Los Banos, East-West Center, Honolulu, Hawaii. $\square$

Conway GR. 1986. Agroecosystem Analysis for Research and Development. Winrock International. Bangkok, Thailand.

Dove MR. 1985. Swidden Agriculture in Indonesia: the subsistence strategies of Kalimantan Kantu. Mouton, Berlin.

Ellen R (ed), Modern Crises and Traditional Strategies: Local Ecological Knowledge in Island Southeast Asia. Berghahn Books, New York.Oxford.

Fox JJ. 1991. Managing the ecology of rice production in Indonesia. In Hardjono J (ed), Indonesia: Resouces, Ecology, and Environment. Oxford University Press, Singapore. 
Hardjasaputra A, Sobana. 2009. Ngahuma, A Traditional Agricultural Pattern in West Java, Historical Review. University of Padjadjaran, Sumedang. [Indonesian]

Iskandar J, Abdoellah OS.1988. Agroecosystem Analysis: A Case Study in West Java. Rerkasem K and AT Rambo (eds), Agroecosystem Research for Rural Development. MCC Chiang Mai University and SUAN in Cooperation with The East-West Center Environment and Policy Institute, Hawaii.

Iskandar J, Ellen R. 2007. Innovation, 'Hybrid' Knowledge and the Conservation of Relict Rainforest in Upland Banten. In Ellen R. (ed), Modern Crises and Traditional Strategies: Local Ecological Knowledge in Island Southeast Asia. Berghahn Books, New York.Oxford.

Iskandar J, Iskandar BS, Partasasmita R. 2016. Responses to environmental and social-economic changes in the Karangwangi traditional agroforestry, South Cianjur, West Java. Biodiversitas 17 (1): 332-341.

Iskandar J, Iskandar BS, Partasasmita R.2018. Strategy of the Outer Baduy Community of South Banten (Indonesia) to sustain their Swidden Farming Traditions by Temporary Migration to Non-Baduy area. Biodiversity 19 (2): 453-464.

Iskandar J, Iskandar BS. 2011. Agroecosystem of Sundanese People. PT. Kiblat Buku Utama, Bandung [Indonesian].

Iskandar J, Iskandar BS. 2015. Ethnobotany study on ethnobotany food plant of "sistem huma" to support food security of Baduy Community. Pros Sem Nas Masy Biodiv Indon 1 (6): 1265-1272.

Iskandar J, Iskandar BS. 2016. Resilience of Baduy Traditional Agroforestry System in Response to Environmental and SocioEconomic Changes. Journal of Indonesia History 4 (1): 19-24.

Iskandar J. 1991. An Evaluation of the Shifting Cultivation System of the Baduy Society in West Java using modeling. [Thesis] Chiang Mai University, Chiang Mai, Thailand.

Iskandar J. 1998.Swidden as a form of cultural identity: The Baduy case. (Dissertation). University of Kent, Canterbury, UK. $\square$

Iskandar J. 2006. Methodology for understanding farmers and agriculture Jurnal Analisis Sosial 11 (1): 171-201.

Iskandar J. 2007. Responses to Environmental Stress in the Baduy Swidden System, South Banten, Java. In

Iskandar J. 2012a. Ethnobiology and Sustainable Development. AIPI Bandung, Puslitbang KPK LPPM Unpad [Indonesian].

Iskandar J. 2012b. Ecology of Swidden Farming of Baduy Community: Sustainable Management of Forest based on culture. PT. Alumni, Bandung [Indonesian].

Jamaludin. 2012. Symbolic Meaning of Swidden (Huma) of Baduy Community. Jurnal of Humanism 11 (1): 2012-01 [Indonesian].

Johnson A, Earle T. 1987. The Evolution of Human Society for Foraging Group to Agrarian State. Standford University Press, Standford, California.
Lahajir. 2002. Ethnoecology of Swidden Farming among Dayak People of Tunjungan Linggang. Gilang Press, Yogyakarta [Indonesian].

Lynch S JF, Hoelnsteiner RM, Cover CL. 1974. Data Gathering by Social Survey. Philippine Social Science Council, Quezon City.

Marten GG. 1988. Measurement Problems in Agroecosystem Analysis: A Critique of System Properties. In Rerkasem K and AT Rambo (eds), Agroecosystem Research for Rural Development. MCC Chiang Mai University and SUAN in Cooperation with the East-West Center Environment and Policy Institute, Hawaii.

Martin GJ. 1995. Ethnobotany: A Methods Manual. Chapman \& Hall, London.

Newing H, Eagle CM, Puri RK, Watson CW. 2011. Conducting Research in Conservation: A Social Science Perspective. Routledge, London. $\square$

PPSDAL. 2014 \& 2017. Report on Biodiversity Management Plant (BMP) of Upper Cisokan Upper Pumped Storage. PPSDAL/Institute of Ecology, LPPM, Padjadjaran University.

PLN. 2007. Environmental Impact Assessment. [Progress report] Upper Cisokan Pumped Storage (UCPS) Bandung District and Cianjur District West Java Province. Indonesia

Ramakrishnan PS. 2015. Shifting Agriculture and Fallowed Management Options: Where do we stand? In: Cairns MF. (ed), Shifting Cultivation and Environmental Change: Indigenous People, Agriculture and Forest Conservation. Routledge, London.

Rambo AT. 1984. No Free Lunch: A Reexamination of the Energetic Efficiency of Swidden Agriculture. In Rambo AT, Sajise PE. (eds). An Introduction to Human Ecology Research on Agricultural Systems in Southeast Asia.East-West Environment and Policy Institute and University of the Philippines at Los Banos, East-West Center, Honolulu, Hawaii.

Reijntjes C, Haverkort B, Waters-Bayer, 1992. Farming for the future: An introduction to Low-External-Input and Sustainable Agriculture. MacMillan, London. $\square$

Rerkasem B, Shinawatra B. 1988. On the Systems Properties of the Chiang Mai Valley Agroecosystem: Implications for Development. In: Rerkasem K, Rambo AT (eds). Agroecosystem Research for Rural Development. MCC Chiang Mai University and SUAN in Cooperation with the East-West Center Environment and Policy Institute, Hawaii. $\square$

Sanwal M. 1989. What We Know About Mountain Developments. Mountain Res Dev 9 (1): 3-14.

Soemarwoto O. 1980. Interrelations among population, resources, environment and development in the ESCAP Region with special reference to Indonesia. Ecology and Development. Publication No. 7. Institute of Ecology. Padjadjaran University, Bandung.

Weinstock JA. 2015. The Future of Swidden Cultivation. In Cairns MF (ed), Shifting Cultivation and Environmental Change: Indigenous People, Agriculture and Forest Conservation. Routledge, London.

Winarto YT. 2016. Food Crisis and Prevented Though: Why Still Continue?. Yayasan Pustaka Obor Indonesia, Jakarta. [Indonesian] 